\title{
Research \\ Growing into Interdisciplinarity: How to Converge Biology, Economics, and Social Science in Fisheries Research?
}

\author{
$\underline{\text { Päivi Haapasaari }}^{1}, \underline{\text { Soile Kulmala }}^{2,3,4}$, and Sakari Kuikka $^{1}$
}

\begin{abstract}
It has been acknowledged that natural sciences alone cannot provide an adequate basis for the management of complex environmental problems. The scientific knowledge base has to be expanded in a more holistic direction by incorporating social and economic issues. As well, the multifaceted knowledge has to be summarized in a form that can support science-based decision making. This is, however, difficult. Interdisciplinary skills, practices, and methodologies are needed that enable the integration of knowledge from conceptually different disciplines. Through a focus on our research process, we analyzed how and what kind of interdisciplinarity between natural scientists, environmental economists, and social scientists grew from the need to better understand the complexity and uncertainty inherent to the Baltic salmon fisheries, and how divergent knowledge was integrated in a form that can support science-based decision making. The empirical findings suggest that interdisciplinarity is an extensive learning process that takes place on three levels: between individuals, between disciplines, and between types of knowledge. Such a learning process is facilitated by agreeing to a methodological epochè and by formulating a global question at the outset of a process.
\end{abstract}

Key Words: Baltic Sea salmon fisheries; Bayesian beliefnetworks; bioeconomic modeling; integrated model; interdisciplinarity, interdisciplinary learning; fisheries research; methodological epochè; multidisciplinarity

The only way to learn the rules of this Game of games is to take the usual prescribed course, which requires many years; and none of the initiates could ever possibly have any interest in making these rules easier to learn. (from The Glass Bead Game, by Hermann Hesse, Nobel laureate in literature 1946)

\section{INTRODUCTION}

The importance of tackling complex environmental problems through integrating knowledge across disciplinary boundaries is increasingly emphasized (Ludwig 2001). In the fisheries management field, the European Community requires the quality of scientific advice related to the exploitation of fish resources to be improved through incorporating economic and social factors (Commission of the European Communities 2003, 2008), and the request to create holistic fisheries analyses is expressed in funding calls (e.g., Baltic Organisations Network for Funding (BONUS) 2010-2016), reports (Sissenwine and Symes 2007), conferences (Kuikka et al. 2009), and scientific papers (Garcia and Charles 2008). These requests awake a need to develop interdisciplinary skills, practices, and methods.

Interdisciplinarity is not, though, a new phenomenon (Klein 1990); neither is the observation that it is a difficult and timeconsuming area of research. The literature analyzes interdisciplinary challenges caused by, for example, the differences in disciplinary practices and paradigms, the absence of established frameworks and models to link different kinds of data, the requirements faced by the researchers to deal with more than one field, and the insufficient institutional facilities, and it proposes practical and methodological solutions (Daily and Ehrlich 1999, Golde and Gallagher 1999, Naiman 1999, Pickett et al. 1999, Redman 1999, Turner and Carpenter 1999, Pavao-Zuckerman 2000, Heemskerk et al. 2003, MacMynowski 2007, Strang 2009, Nuijten 2011).

An important but rather absent topic in the interdisciplinary literature is the empiria of interdisciplinary processes (Furman et al. 2009). Klein (1990) has called for compiling narratives and conducting empirical studies of interdisciplinary research practices, to reach a fuller understanding on interdisciplinarity. Lattuca (2002) emphasizes the importance of examining how individuals appropriate cultural tools needed for interdisciplinary work. Huutoniemi et al. (2010) stress the need of empirical analyses to test and validate existing conceptual categorizations on the issue and to further develop analyses or evaluation tools.

By focusing on our own research process, we analyzed how and what kind of interdisciplinarity between natural scientists (seven people: fisheries science, fish biology, mathematics), environmental economists (three people), and social scientists (three people: sociology, anthropology) grew from the need to better understand the complexity related to salmon fisheries in the Baltic Sea, and how data from these conceptually different fields were integrated. The aim of the paper is to bring new aspects to the discussion on interdisciplinarity and to the development of interdisciplinary procedures.

\footnotetext{
${ }^{1}$ Fisheries and Environmental Management Group, Department of Environmental Sciences, University of Helsinki, ${ }^{2}$ Marine Research Centre, Finnish Environment Institute, ${ }^{3}$ MTT Agrifood Research, Finland, ${ }^{4}$ Finnish Game and Fisheries Research Institute
} 


\section{THE GLASS BEAD GAME}

There is not much consensus on what interdisciplinarity means. It is commonly used both to denote any collaboration between disciplines, and as a certain form distinguished from multidisciplinarity and transdisciplinarity (Klein 1990, Huutoniemi et al. 2010). Huutoniemi et al. (2010) propose a typology to indicate dissimilar modes in collaboration between disciplines (Table 1). They define multidisciplinarity as subprojects linked loosely by a topic or a common problem setting, or as a juxtaposed combination of expertise to produce new knowledge, without significant interaction between disciplines. Interdisciplinarity, on the contrary, is defined as the integration of data, methods, theories, concepts, or models that build on interaction. Transdisciplinarity is increasingly seen as a hybrid of scientists and stakeholders, science and practice, and scientific and nonscientific knowledge (Klein et al. 2001).

Table 1. A typology of multidisciplinarity and interdisciplinarity, according to Huutoniemi et al. (2010).

\begin{tabular}{|c|c|}
\hline $\begin{array}{l}\text { Mode of } \\
\text { collaboration }\end{array}$ & Description \\
\hline $\begin{array}{l}\text { Encyclopedic } \\
\text { multidisciplinarity }\end{array}$ & $\begin{array}{l}\text { Subprojects from different fields are linked } \\
\text { loosely by a topic, and the disciplines work } \\
\text { with separate problems using their own } \\
\text { methodology. }\end{array}$ \\
\hline $\begin{array}{l}\text { Contextualizing } \\
\text { multidisciplinarity }\end{array}$ & $\begin{array}{l}\text { Knowledge is produced in a context in relation } \\
\text { to problem setting, which binds research } \\
\text { groups with related interests. }\end{array}$ \\
\hline $\begin{array}{l}\text { Composite } \\
\text { multidisciplinarity }\end{array}$ & $\begin{array}{l}\text { Elements, research tasks, or knowledge are } \\
\text { externalized or transferred in a modularized } \\
\text { way from one field to another as a } \\
\text { combination of expertise, but interaction is } \\
\text { technical rather than dialogic. }\end{array}$ \\
\hline $\begin{array}{l}\text { Empirical } \\
\text { interdisciplinarity }\end{array}$ & $\begin{array}{l}\text { Data are integrated to examine relationships } \\
\text { between phenomena or to produce a } \\
\text { combination of evidence to solve a problem. }\end{array}$ \\
\hline $\begin{array}{l}\text { Methodological } \\
\text { interdisciplinarity }\end{array}$ & $\begin{array}{l}\text { A combination of different methodological } \\
\text { approaches in an integrated manner. }\end{array}$ \\
\hline $\begin{array}{l}\text { Theoretical } \\
\text { interdisciplinarity }\end{array}$ & $\begin{array}{l}\text { Theories, concepts, or models are synthesized } \\
\text { to devise new theoretical approaches for } \\
\text { interdisciplinary analyses. }\end{array}$ \\
\hline
\end{tabular}

Klein (1990) stresses that interdisciplinarity is not a subject matter or a body of content, but a process that begins with a problem or topic and aims at an integrative synthesis. She refers to DeWachter's (1982) distinction of five phases in an ideal interdisciplinary process, conceptualized around a methodological epochè [ERRATUM]:
1. All disciplines accept the methodological epochè by abstaining from approaching the topic by their monodisciplinary methods.

2. A global question is formulated in an interdisciplinary way by acknowledging all the aspects and the total network.

3. The global question is translated into the specific language of each participating discipline.

4. The particular answer to this translated question is constantly checked for its relevance in answering the global question.

5. A global answer produced by integrating all particular answers is agreed upon.

Due to troublesome interaction between disciplines, interdisciplinary processes rarely follow such a straightforward line (Klein 1990). Academic disciplines have been described as self-regulating and self-sustaining "tribes" that inhabit their own territories and define their own identities and social practices (Becher 1989). The disciplines frame, and thus limit, the thinking and intellectual activity of their practitioners, and this makes encountering disciplinary cultures all the more difficult the farther the fields are from each other (Becher 1989, Bradshaw and Bekoff 2001).

Thus, interdisciplinarity requires the tribes to learn how to communicate across the disciplinary boundaries (Bradshaw and Bekoff 2001). The socio-cultural learning theories see learning as a cognitive process that takes place in social interaction, embedded in its (immediate and wider) historical, cultural, and social contexts. Interaction is mediated by cultural tools that provide bridges and shape the action between the individual and the world (Wertsch et al. 1995, Lattuca 2002). By appropriating cultural tools from each other, partners develop an increasing intersubjectivity that leads to mutual understanding, prepares the participants for subsequent involvement in related activities, and reproduces and changes the existing cognitive and social order (Wertsch et al. 1995, Rogoff 1995). Rogoff (1995) stresses that learning means change not only on the personal level, but also on the interpersonal and community levels. It can lead to development in the community, but alternatively to divergent perspectives and disharmony (Lattuca 2002). In interdisciplinary learning, a researcher appropriates concepts, perspectives, or methods of another discipline; lets them inform his/her own understanding of the problem; and transforms them for his/ her own use and for integrating knowledge (Lattuca 2002, Sillitoe 2004).

\section{MATERIAL AND METHODS}

This paper is based on an ethnographic study (Brewer 2005) of our own interdisciplinary research process, conducted from 2003 to 2010 by the first author of this paper, a social scientist. 
Difficulties in agreeing on a methodological epochè at the start of the process awoke her interest and she got the idea of studying the process in addition to her work in the project. She observed the project meetings and other collaborative occasions and discussed with the researchers, utilizing her existing role as a member of the group ("observant participation", Brewer 2005). At the end (2006) of the first project (Step 1) she carried out seven thematic interviews of key people, i.e., people who had participated in most of the interdisciplinary activities. The interviews concerned the different ways that collaboration took place or could have taken place, the possibilities for integrating knowledge from conceptually different fields, the difficulties of interdisciplinary collaboration, and the researchers representing different fields as cooperators. After publishing a paper focusing on the interdisciplinarity in Step 1 (Haapasaari 2008) the social scientist continued observing and discussing the subsequent projects (Step 2, Step 3), and the theme was referred to in the interviews of the group members that focused on salmon management, which were carried out from 2008 to 2009. The final data set comprised field notes, recordings and their transcripts, and project documents. In the analysis, the QSR NVivo software, which was designed to manage, arrange, and sort qualitative data (Bazeley 2007), was used. Finally the data were interpreted against the theoretical aspects.

The twofold role of the social scientist as a subject (researcher) and as an object (member of the group that she studied) resulted in rich and many-sided material regarding the social reality of the group. As an observer participant she reflected the views of the other researchers to her own experience on the interdisciplinary process. Potential bias and misinterpretations were controlled by combining the several data-collection methods (triangulation, Brewer 2005), and by inviting an economist and a fisheries scientist of the group to "membercheck" (Schwartz-Shea 2006) the viability of the interpretation and to cowrite this article.

\section{THREE STEPS TO CONVERGING DISCIPLINES}

\section{Baltic salmon: a schoolbook example of a complex management problem}

Most of the Baltic Sea wild salmon stocks have been destroyed or depleted during the twentieth century, and the remaining ones are of different status (International Council for the Exploration of the Sea 2010). The management of the stocks that migrate between their natal rivers and the feeding area in the Baltic Main Basin balances between uncertainties related to the state of the stocks and the interests of several stakeholder groups in different Baltic Sea countries. Thus, there is constant dispute over whether and where salmon should be fished, and by whom, as well as how and to what extent (Finnish Game and Fisheries Research Institute 2009, Salmi and Salmi 2010). In 1997, an international salmon stock restoration program, the Baltic Salmon Action Plan (SAP), was established to support the management and scientific advisory work related to the salmon stocks until 2010 (Ranke et al. 1999). After that, a new long-term management plan was designed to continue the restoration process (Commission of the European Communities 2009). The fisheries scientists referred to in this paper chaired and participated in the stock assessment group of Baltic salmon of the International Council for the Exploration of the Sea (ICES) and contributed to realizing the Salmon Action Plan in Finland, and had noticed that scientific knowledge related to the human aspect was missing from salmon research and management:

There is a human being between the decision and the impact of the decision in the nature, and if we describe the human behavior inadequately, we get a too optimistic view on what we can reach with the regulation. (fisheries scientist, 2006)

Step 1: Baltic Salmon Action Plan in the Bothnian Bay rivers: interdisciplinary modeling of the evolving salmon stocks and socioeconomic aspects, 2003 to 2005

Our project, which was called the "Baltic Salmon Action Plan in the Bothnian Bay rivers: interdisciplinary modeling of the evolving salmon stocks and socioeconomic aspects" (also generally referred to as BIREME-SAP) (Table 2), was funded by the Baltic Sea Research Programme (BIREME) (2007) of the Academy of Finland; the latter stressed interdisciplinary research and enabled considerations on the restoration of the salmon stocks to be expanded in a more holistic direction. The starting point of the project was a wide interdisciplinary question: How to justify the socioeconomic feasibility of the Salmon Action Plan to local communities, and help them cooperate in achieving the common goals, under high uncertainty about the state of the salmon stocks? The project's aim was to develop an interdisciplinary decision support tool through a methodological epochè:

In this study we combine the relatively well known Baltic salmon stock dynamics with the less known socioeconomic dynamics of different groups of fishermen in the sea, in the coastal and estuarine areas, and in the river valleys. We apply probabilistic Bayesian methods and create decision models, which take into account the uncertainties related to biological and human subcomponents of the system. We further develop these models to management models, i.e., models where the human and biological elements can be analyzed and incorporated into management actions. (research proposal of Baltic Sea Research Programme-Salmon Action Plan).

The methodological epochè meant the application of the Bayesian approach (Jensen 2001) in each substudy and in integrating knowledge from the different fields. It was defined by the fisheries scientists who represented the state of the art of the Bayesian methodology in their own field (Varis and 
Table 2. The three projects (Steps 1, 2, and 3) in a nutshell.

\begin{tabular}{|c|c|c|c|}
\hline $\begin{array}{l}\text { Interdisciplinary } \\
\text { collaboration }\end{array}$ & $\begin{array}{c}\text { Step 1: } \\
\text { BIREME-SAP, 2003-2005 }\end{array}$ & $\begin{array}{c}\text { Step 2: } \\
\text { Salmon Action Plan impact assessment, } \\
2007-2008\end{array}$ & $\begin{array}{c}\text { Step 3: } \\
\text { Integrated model, 2009-2010 }\end{array}$ \\
\hline Funding & The Academy of Finland & European Commission & None \\
\hline Aims & $\begin{array}{l}\text { Increase knowledge of a complex fishery } \\
\text { problem, and develop an interdisciplinary } \\
\text { decision support tool. }\end{array}$ & $\begin{array}{l}\text { Impact assessment of the Salmon Action } \\
\text { Plan }\end{array}$ & $\begin{array}{l}\text { Integrate biological, economic, and social } \\
\text { knowledge in a decision support model }\end{array}$ \\
\hline $\begin{array}{l}\text { Research } \\
\text { questions }\end{array}$ & $\begin{array}{l}\text { How to deal with the high uncertainty in } \\
\text { assessing the status of individual salmon } \\
\text { stocks and in setting management objectives? } \\
\text { How to justify the socioeconomic feasibility } \\
\text { of a salmon stock restoration program to the } \\
\text { local communities? How to help the local } \\
\text { communities to cooperate for achieving the }\end{array}$ & $\begin{array}{l}\text { What are the biological, economic, and } \\
\text { social impacts of the Salmon Action Plan and } \\
\text { certain new management options and } \\
\text { objectives for the future? }\end{array}$ & $\begin{array}{l}\text { Which long-term management objective } \\
\text { would lead to best implementation success of } \\
\text { individual management measures in terms of } \\
\text { fishers' commitment, and further to best } \\
\text { biological, commercial, recreational and/or } \\
\text { social utility? }\end{array}$ \\
\hline
\end{tabular}

Publication Commitment to salmon: using Bayesian titles modeling to create a sustainable fisheries management tool based on commitment of fishermen

(Haapasaari et al. 2005)

A bioeconomic analysis of the Northern Baltic salmon

fishery: management of competing sequential fisheries (Kulmala et al. 2005)

Interdisciplinary modeling through probabilistic networks: impact of fishermen's commitment on the management of wild Baltic salmon stocks (Michielsens et al. 2005a)

Interdisciplinary probabilistic network to examine the possibility to restore potential Baltic salmon rivers (Michielsens et al. 2005b)

Reconciling economic and biological modelling of migratory fish stocks: optimal management of the northern Baltic salmon fishery (Kulmala et al. 2006)

A Bayesian state-space mark-recapture model to estimate exploitation rates in mixed-stock fisheries (Michielsens et al. 2006b)

Estimation of annual mortality rates caused by early mortality syndromes (EMS) and their impact on salmonid stock-recruit relationships (Michielsens et al. 2006a)

Management measures and fishers' commitment to sustainable exploitation: a case study of Atlantic salmon fisheries in the Baltic Sea (Haapasaari et al. 2007)

Reconciling economic and biological modeling of migratory fish stocks: optimal management of the Atlantic salmon fishery in the Baltic Sea (Kulmala et al. 2008)

Combining multiple Bayesian data analyses in a sequential Bayesian framework for quantitative fisheries stock assessment (Michielsens et al. 2008)
The Report of the Data Analysis to Support the Development of a Baltic Sea Salmon Action Plan, S12.491891, FISH/2007/03Lot 6 (Finnish Game and Fisheries Research Institute 2009)

Formalizing expert knowledge to compare alternative management plans: sociological perspective to the future management of Baltic salmon stocks (Haapasaari and Karjalainen 2010)
Synthesizing biological, economic and sociological knowledge using Bayesian Belief Networks to support broadly based fisheries policy: the case of devising a new Baltic salmon management plan (Levontin et al. 2009)

Integration of biological, economic and sociological knowledge by Bayesian belief networks: the interdisciplinary evaluation of potential Baltic salmon management plan (Levontin et al. 2011) 


\begin{tabular}{|c|c|c|c|}
\hline \multirow[t]{3}{*}{$\begin{array}{l}\text { Forms of } \\
\text { collaboration }\end{array}$} & $\begin{array}{l}\text { Natural scientists and social scientists: } \\
\text { composite multidisciplinarity }\end{array}$ & $\begin{array}{l}\text { Natural scientists and social scientists: } \\
\text { composite multidisciplinarity }\end{array}$ & All scientists: theoretical interdisciplinarity \\
\hline & $\begin{array}{l}\text { Natural scientists and economists: } \\
\text { methodological interdisciplinarity }\end{array}$ & $\begin{array}{l}\text { Natural scientists and economists: } \\
\text { methodological interdisciplinarity }\end{array}$ & \\
\hline & $\begin{array}{l}\text { Economists and social scientists: } \\
\text { contextualizing multidisciplinarity }\end{array}$ & $\begin{array}{l}\text { Economists and social scientists: } \\
\text { contextualizing multidisciplinarity }\end{array}$ & \\
\hline \multirow{2}{*}{$\begin{array}{l}\text { Aim vs. } \\
\text { output }\end{array}$} & Aim: theoretical interdisciplinarity & Aim: composite multidisciplinarity & Aim: theoretical interdisciplinarity \\
\hline & Output: contextualizing multidisciplinarity & Output: composite multidisciplinarity & Output: theoretical interdisciplinarity \\
\hline
\end{tabular}

Kuikka 1997, Mäntyniemi and Romakkaniemi 2002, International Council for the Exploration of the Sea 2002, Michielsens and McAllister 2004, Mäntyniemi et al. 2005, Uusitalo et al 2005, Michielsens et al. 2006a, Michielsens et al. 2006b, Michielsens et al. 2008). The idea of the approach is to update prior knowledge, expressed as probability distributions, with new knowledge to get a posterior understanding of the problem. There exists no objective value for a probability, which implies that the probability distribution is based on a subjective degree of belief. The methodology allows the modeling of pure expert knowledge in addition to data analysis. Thus, the approach was quite the contrary to the conventional frequentist statistics striving for objectivity (Malakoff 1999), and the fisheries scientists had both contributed to a debate within the international community of fisheries scientists and had struggled to get their approach accepted by the International Council for the Exploration of the Sea. Neither the economists nor the social scientists had any prior involvement in the approach.

The social scientists accepted the Bayesian approach even though reducing human behavior into a model of causalities felt, at first, inconvenient. They considered the method compatible with their own thinking: the subjectivist Bayesian approach shared the idea of pre-understanding with the hermeneutic theory, and acknowledged the socially constructed character of knowledge (Berger and Luckmann 1966, Upshur 1999, Gadamer 2004). In addition to that, the holistically oriented anthropology formed a favorable ground for the idea of integrating knowledge. Data were collected and analyzed using sociological methods, and were further structured into a Bayesian belief network (BBN) model (Haapasaari et al. 2007). A fisheries scientist, specialized in the Bayesian method, familiarized a social scientist with the method, and contributed to technical details.

The economists, on the contrary, saw that the project plan did not bind them to the method. In the interview one of the economists said they did not believe in the possibilities of Bayesian belief networks in dynamic optimization, that they considered the threshold of publishing papers in their journals of interest too high for such a method, and that they preferred realizing the $\mathrm{Ph}$.D. thesis planned as an outcome of the study by applying the traditional paradigm of natural resource economics. In the first project meetings, long debates between the fisheries scientist responsible for the project plan and the economists culminated in hot disputes, which the fisheries scientist recalled a few years later:

Right at the beginning, it became clear that the economists did not have any motivation to play the common game, and I realized that it was no use to even try, so we had to knuckle under the fact that they have another perception of good science. (fisheries scientist, 2006)

As a result, the economists constructed a bioeconomic optimization model, assisted by a fisheries scientist (Kulmala et al. 2008). One of the fisheries scientists explained later that he and his colleagues agreed with the modeling technique because its biological part was similar to the population model used by the natural scientists. Despite this they kept on criticizing the naivety of the bioeconomic models in describing reality, and the uselessness of optimization studies in fisheries management. Due to this, the economists felt they were treated unjustly and that their work was undervalued. There also emerged friction in relation to the allocation of resources:

It is easy to underestimate another discipline, to wonder what is the difficulty there if you see only some really reduced and simplified part of it, and you don't understand the methods, you cannot know what amount of work there is behind that work, and if you don't know the literature of that discipline, you cannot understand what is the contribution of that study compared to the previous studies. (economist, 2006)

While both the economists and the social scientists collaborated with the natural scientists, the social scientists and economists did not interact scientifically, and their relationship was based only on the project context and a common interest in the problematic issue of salmon stock restoration. Although it was hard for the social scientists and economists to understand each other scientifically, in the project meetings they built good personal relationships between each other. A social scientist characterized the distance between economics and sociology in an interview: 
The perspective of economics sounded very abstract at the beginning, and I didn't understand anything. It was like, like they would have been talking about anything else but fish, fishing, and fishers. Terrifying mathematical formulas, methods, and concepts. We used to say that the economists have clean models whereas we have dirty hands. (social scientist, 2006)

The group was not able to agree on a global question. All the disciplines concentrated on their own studies, and cognitive interaction between the three disciplines was restricted to problem setting. Reflecting to the typology of Huutoniemi et al. (2010), the project aimed at theoretical interdisciplinarity, but remained at the level of contextualizing multidisciplinarity. Despite this, the evaluation report of the BIREME research program mentioned this project as one of the very few projects in which interdisciplinary research took place (Baltic Sea Research Programme 2007). The final report of the project comprised three separate studies, and conclusions. The report stated: "A major step towards true interdisciplinary research has, however, been taken within the project to achieve synthesis across different research fields, but still, further integration is needed in the future and even better cooperation is possible." Two conference papers outlined the plans for the interdisciplinary model and its potential (Michielsens et al. 2005a, 2005b).

\section{Step 2: data analysis to support the development of a Baltic Sea salmon management plan (Salmon Action Plan impact assessment), 2007 to 2008}

In Step 2, almost the same group of researchers responded to a call for tenders of the European Commission considering the assessment of impacts of the Salmon Action Plan and new management options and objectives for the future (Table 2). A socioeconomic impact assessment was to be synthesized with an International Council for the Exploration of the Sea (ICES) report including the biological evaluation of the Salmon Action Plan, to provide an impact assessment report (Finnish Game and Fisheries Research Institute 2009, Commission of the European Communities 2009). The call required bioeconomic modeling, but did not define the approach or contents of the social impact assessment. Thus the project did not aim at interdisciplinarity between three disciplines.

The fisheries scientists led the project and were responsible for putting together the report. The social scientists again used the Bayesian method in their study (Finnish Game and Fisheries Research Institute 2009, Haapasaari and Karjalainen 2010). They saw the method as being useful for the evaluation of the long-term management options, because it enabled verbal information to be condensed into easily comparable quantitative values, because the information could potentially be combined with knowledge from other fields, and because it allowed the use of a small data set (Finnish Game and
Fisheries Research Institute 2009, Haapasaari and Karjalainen 2010). They were now able to carry out the modeling without help from natural scientists, but needed them to define the details for a survey. The economists built a bioeconomic simulation model of the salmon fishery with the fish biologists (Finnish Game and Fisheries Research Institute 2009).

All of the four full-time researchers of the project now worked at the same campus, unlike during Step 1, when they worked in two different cities and three different institutes. Thus, besides the fact that Step 2 was an important continuation of formal meetings, it meant enhancing informal interaction in terms of common lunches, coffees, and evening parties. These provided opportunities to get to know each other, and to ask "stupid" questions, and through this to clarify the roles and approaches in the interdisciplinary wholeness. Open discussion on the importance of the interdisciplinary work in environmental research and related job opportunities motivated the researchers, and a common language around fisheries management and an interdisciplinary field and interdisciplinary identity developed.

\section{It is hard to get into a situation in which the common language can be found and in which we can start benefiting from it. But I think that the more there are people who have worked interdisciplinarily, the easier it will be, and now I think that in the next projects it will be much easier. The pain has been suffered now and you can do it and you have developed the ability to present things in a different way and do not take certain things as self-evident, and you learn so much, and you learn from the other discipline too, that's really fruitful experience. (economist, 2008)}

In Step 2, the research was carried out in the manner of composite multidisciplinarity: it was a combination of expertise in a modularized way to produce new knowledge. In the report the different substudies were described separately and in the summary they were combined to make conclusions and recommendations (Commission of the European Communities 2009, Finnish Game and Fisheries Research Institute 2009). The results of the different studies supported each other (Finnish Game and Fisheries Research Institute 2009), which encouraged the researchers to take the next step.

\section{Step 3: integrated model, 2009 to 2010}

In Step 3, the holistic decision support model for the long-term management of the Baltic salmon stocks was finally realized and the aim of theoretical interdisciplinarity was achieved, without special funding applied for the task (Table 2). The initiative came from the social scientist who had carried the main responsibility of the social science work in Steps 1 and 2 , and who had both personal and scientific ambitions to see whether the methodological epochè was possible. She had received criticism from her social science colleagues who did 
Fig. 1. The integrated Bayesian belief network (BBN) model, modified from the model published by Levontin et al. (2011). Parts produced by different disciplines are indicated by different colors. The model allows examination of how the results of the bioeconomic model (regarding optimal management) would change if the effect of the implementation uncertainty (resulting from fishers' commitment to alternative management objectives) were taken into account in a quantitative manner. The model also makes it possible to compare different management objectives and options in terms of biological, commercial, recreational, and social utility (Levontin et al. 2011).

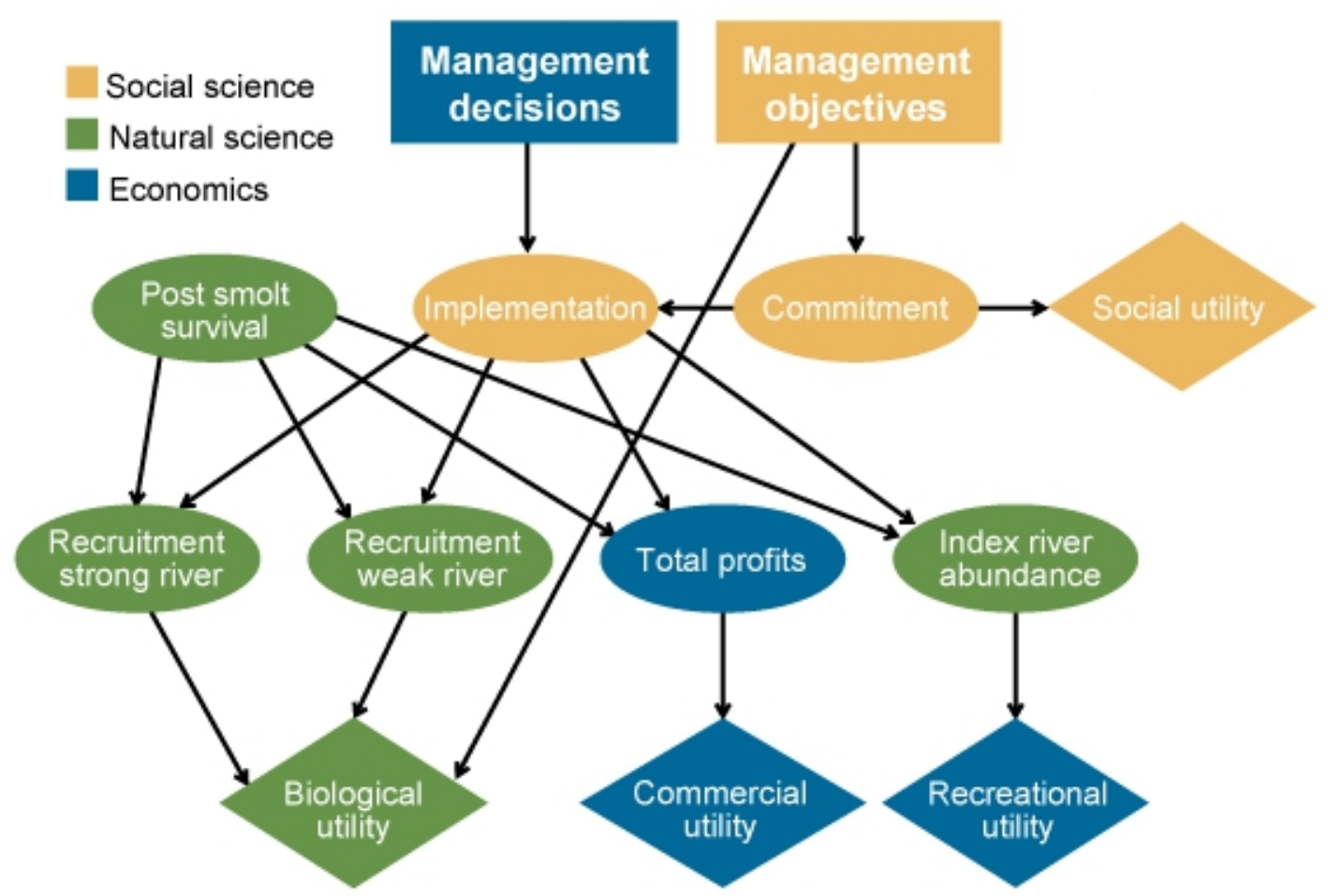

not believe in integrative analytical frameworks in environmental problem solving and did not accept the paralleling of human behavior with interrelationships in the nature. After accomplishing the integrated model, the social scientist reflected on her motivation:

It was important for me to see this done. I felt that this kind of integrating is something that is really necessary to be done and to be presented to the scientific community, to show that it is possible. But perhaps I also had a more personal interest in it. I believe that by accomplishing the integrated model I could justify that it made sense to build Bayesian models from the pure social scientific data, for myself and for my colleagues, who had questioned it, wondered why we made it so complicated, and why we let the natural scientists dictate what to do. (social scientist, 2010)

The economist had nearly completed her Ph.D. thesis, had participated in Bayes courses, and was now willing to try the modeling as extra work and with the principle "nothing to lose". When deciding on the common effort, she explained she felt it was necessary to synthesize the multidisciplinary results of Step 2 through an interdisciplinary model. Two natural scientists - a methodologically oriented mathematician to take responsibility of technical details, and a professor to supervise-were asked to join in the project.

In Step 3, the methodological epochè and the biological, economic, and social aspects in the total network were the starting point for answering the global question adopted from Step 2, where the different disciplines had produced separate results and the synthesis had been made verbally. Now the results of Step 2 were to be synthesized quantitatively in a Bayesian belief network model (Fig. 1, Levontin et al. 2011). The global question was translated into the specific language of each discipline and a global answer was produced by translating the particular answers into the probabilistic language of the Bayesian belief networks, and by integrating them in the interdisciplinary model. 
The disciplinary work was conducted by the scientists separately, but the applicability, relevance, and reasonableness of every phase was checked together in common modeling sessions for which time was arranged whenever needed. In addition to that, the modeling problems were discussed in informal meetings. A conference paper was jointly written (Levontin et al. 2009), and the model has been presented in conferences of different fields by each researcher of the team. Recently, a paper was published in a peer-reviewed journal (Levontin et al. 2011) and the modeling has led to further project proposals.

\section{Changing your scientific thinking requires that you are given such tools that enable you to choose a new way, and this means that interdisciplinarity requires quite hard training, retraining, and it is a hard way compared to if you just study more and more of one discipline. (fisheries scientist 2006)}

\section{ANALYSIS: LEARNING THE GAME OF GAMES}

The wide cultural context related to fisheries policy making, science, and funding made the time favorable for interdisciplinarity (Baltic Sea Research Programme 2007), but yet the beginning of our process clashed with disciplinary boundaries. The fisheries scientists wanted to solve an interdisciplinary problem using the Bayesian approach that they had applied in biological questions. They had already deviated from the traditional frequentist paradigm of fisheries science and thus tested the boundaries of their discipline, and were ready to respond to the calls of holistic perspectives. For the social scientists, who were used to a wide variety of theories within their field of research, it was relatively easy to accept the new approach that in its epistemological basis was nearer to the theories of social sciences than those of natural sciences. The jump to the reductionist causal thinking of the Bayesian method was long, but its value in the interdisciplinary work was acknowledged. The doubts of other social scientists did not hinder but rather functioned as a catalyst for further development of the application. The fisheries economics was essentially an interdisciplinary field that shared a common interest with fisheries science in developing mathematical models to manage natural resources. The intention of this field towards cumulative growth within its boundaries was so strong that a new approach could not replace its existing paradigm. Thus, on the one hand the bioeconomic modeling functioned as an interdisciplinary link between two disciplines, but on the other hand delayed the agreeing of the methodological epochè between three fields. The economists could accomplish the modeling by initiating a totally new approach only as extra work or as a "hobby".

Owing to this, DeWachter's (1982) ideal model was not realized in our interdisiciplinary process. At the beginning, the methodological epochè could not be agreed on and the global question remained unformulated. Instead of defining all the aspects in the total network and adapting the separate studies to that, the disciplines started the process more or less independently of the other perspectives. The aim of building an interdisciplinary model that included knowledge from three disciplines was, at Step 1, not reached. This aim did not materialize until after an 8-year process of interdisciplinary learning, which included different kinds of multidisciplinary and interdisciplinary substudies and phases (Table 2).

Learning interdisciplinarity meant appropriating cultural tools from each other, and it took place through working together and through continuous discussions. This was faster between natural scientists and economists, and between natural scientists and social scientists, than between economists and social scientists. Finding understanding between these disciplines, although both are often considered social sciences (Rose 1976, Miller 1982), was much harder. For both teams, learning interdisciplinarity with fisheries scientists was so time consuming and intellectually challenging, that they had no resources left for each other, especially in the absence of a common method.

Actually, the whole learning process was the hardest for the economists and the social scientists who had a foot on two fields: they had to master the methodology of their own disciplines and at the same time learn elements related to another discipline and new methods. For the fisheries scientists who represented the official fisheries research, interdisciplinarity meant the others appropriated their cultural tools, whereas they themselves had to learn much less of the other disciplines.

Favorable social context-i.e., good personal relationships and frequent interaction-and the interestingly compatible results of the separately realized studies in Step 2 helped mutual learning progress and find the needed link. Gradually a common language for all the three disciplines developed around Baltic salmon, fisheries management, fishing regulation, profitability, commitment, implementation uncertainty, and the Bayesian belief networks. The fisheries scientists dominated the collaboration at the beginning, but as the social scientists and economists gradually took their role in the wholeness, they also could take more responsibility in the whole. For the integrated model to be built, it was a prerequisite that all equally understood the task.

For the four individuals who carried out the main interdisciplinary work from the beginning, change resulting from the interdisciplinary learning was more obvious than for the others, and around them a small community evolved, involving people more or less engaged in interdisciplinarity. This meant that the interdisciplinary interaction changed towards a more manageable form. It was strongly shaped by the Bayesian approach, which required structuring the problem into factors, causal links, and further to conditional probability tables, and it forced the scientists to communicate in a systematic way. 


\section{CONCLUSIONS}

Huutoniemi et al. (2010) and Klein (1990) emphasize interaction in distinguishing interdisciplinarity from multidisciplinarity. For us, learning was both a requirement for interdisciplinarity, and an indicator of it. Our study required appropriating cultural tools from the other disciplines that changed our thinking, our interaction, and our scientific community.

We see interdisciplinarity as a learning process that takes place on three levels: between individuals, between disciplines, and between types of knowledge. This means, that besides appropriating new cultural tools, we learned to use them in an integrative way. However, integration of knowledge would not have been possible if links between disciplines had not been found, and this required people to be able to communicate with each other.

Through continuous discussion, researchers representing different disciplines learned to understand and respect each other's way of thinking. In our case, small collaborative teams, good personal chemistry, and proximity facilitated this. Scientific ambition and willingness to appropriate new cultural tools, as well as the courage to deviate from the disciplinary mainstream, were essential characteristics of the researchers. Courage was also needed in admitting ignorance or misunderstandings. For this, getting to know each other was important.

Learning between the disciplines meant acknowledging and analyzing the disciplinary differences, and searching for a common territory and a common language to enable the understanding of each other's roles in relation to the problem as well as searching for bridges to integrate knowledge. The flexibility of the disciplinary boundaries in allowing the researchers to step back from the established paradigm was tested. The boundaries of the social sciences and the biological fisheries sciences turned out to be more flexible than those of economics. The Bayesian belief networks, basically situated in no-one's land, finally bridged these three conceptually different fields.

Learning at the level of knowledge meant that the aim of integrating knowledge was achieved. Knowledge produced by one discipline was updated by knowledge produced by another discipline, which required the common probabilistic language for all the data. The integrated model enabled one type of knowledge to be examined in light of another type of knowledge, and it structured the research process. Thus, learning also took place between the model and the researchers.

Writing this paper was a culmination point for our learning: we understand more of the essence of interdisciplinarity now. The writing process convinced us of the importance of the methodological epochè and global question formulation at the outset of a process. We see our future in further developing interdisciplinary approaches based on this finding. The Bayesian methodology provides a promising avenue; however, potential alternative and complementary approaches need to be explored. Another challenge for us will be to facilitate the learning process of others by communicating our experience, especially to Ph.D. students. Are there shortcuts, or must everybody take a prescribed 8-year course?

The Glass Bead Game should admit of everything, even that a single plant should chat in Latin with Linnaeus. (from The Glass Bead Game, by Hermann Hesse, Nobel laureate in literature 1946)

Responses to this article can be read online at: http://www.ecologyandsociety.org/voll7/iss 1/art6/responses/

\section{Acknowledgments:}

The study was carried out with financial support from the European Community's Seventh Framework Programme (FP7/2007-2013) under grant agreement 212969, "Judgement and Knowledge in Fisheries Involving StakeHolders" (JAKFISH). It does not reflect the views of the European Commission and in no way anticipates the Commission's future policy in the area. We thank all the researchers who participated in our projects, especially Catherine Michielsens and Polina Levontin. We also thank Eveliina Klemola for commenting on the paper in its finalization, and the anonymous reviewers and the editors for their valuable comments and suggestions. S. Kulmala acknowledges the funding from The Central Union of Agricultural Producers and Forest Owners (MTK).

\section{LITERATURE CITED}

Baltic Sea Research Programme (BIREME). 2007. Baltic Sea Research Programme BIREME 2003-2006, evaluation report. Publication of the Academy of Finland 5/07, Helsinki. [online] URL: http://www.aka.fi/Tiedostot/Tiedostot/Julkaisu t/5_07_Bireme.pdf.

Bazeley, P. 2007. Qualitative data analysis with NVivo. Sage, London, England. http://dx.doi.org/10.1080/13645570210146285

Becher, T. 1989. Academic tribes and territories: intellectual enquiry and the cultures of disciplines. Open University Press, Suffolk, England.

Berger, P. L., and T. Luckmann. 1966. The social construction of reality: a treatise in the sociology of knowledge. Anchor Books, New York, USA.

Bradshaw, G. A., and M. Bekoff. 2001. Ecology and social responsibility: the re-embodiment of science. Trends in 
Ecology and Evolution 16:460-465. http://dx.doi.org/10.1016/ $\underline{\text { S0169-5347(01)02204-2 }}$

Brewer, J. D. 2005. Ethnography. Open University Press, Oxford, England. http://dx.doi.org/10.1177/0038038594028001014

Commission of the European Communities (CEC). 2003. Communication from the Commission-improving scientific and technical advice for Community fisheries management (2003/C 47/06). Official Journal of the European Union C 47 (46):5-16. http://dx.doi.org/10.1016/0048-9697(87)90392-5

Commission of the European Communities (CEC). 2008. Communication from the Commission to the Council and the European Parliament-the role of the CFP in implementing an ecosystem approach to marine management [SEC (2008) 449]. COM (2008) 187 final, Brussels 11.4.2008. [online] URL: http://eur-lex.europa.eu/LexUriServ/LexUriServ.do?uri= COM:2008:0187:FIN:EN:PDF. http://dx.doi.org/10.1080/138 $\underline{80290902938435}$

Commission of the European Communities (CEC). 2009. Consultation paper to support development of a Baltic salmon management plan. MARE D(2009) 1460 (Annex), Brussels 13.2.2009. Directorate-General for Maritime Affairs and Fisheries. [online] URL: http://ec.europa.eu/fisheries/partners/ consultations/baltic salmon/consultation document en.pdf

Daily, G. C., and P. R. Ehrlich. 1999. Managing Earth's ecosystems: an interdisciplinary challenge. Ecosystems 2:277-280. http://dx.doi.org/10.1007/s100219900075

DeWachter, M. 1982. Interdisciplinary bioethics: but where do we start? A reflection on epochè as method. Journal of Medicine and Philosophy 7:275-87.

Finnish Game and Fisheries Research Institute. 2009. The report of the data analysis to support the development of a Baltic Sea Salmon Action Plan, SI2.491891, FISH/2007/03Lot 6. Helsinki, Finland. [online] URL: http://ec.europa.eu/fi sheries/documentation/studies/baltic_sea_salmon_en.pdf.

Furman, E., T. Peltola, and R. Varjopuro (editors). 2009. Interdisciplinary research framework for identifying research needs. Case: bioenergy-biodiversity interlinkages. The Finnish Environment 17/2009. Finnish Environment Institute, Helsinki, Finland. [online] URL: http://www.ymparisto.fi/do wnload.asp? contentid=102134\&lan=en.

Gadamer, H. G. 2004. Truth and method. Continuum Publishing Group, Chippenham, Wiltshire, England.

Garcia, S. M., and A. T. Charles. 2008. Fishery systems and linkages: implications for science and governance. Ocean and Coastal Management 51:505-527. http://dx.doi.org/10.1016/j. ocecoaman.2008.05.001
Golde, C. M., and H. A. Gallagher. 1999. The challenges of conducting interdisciplinary research in traditional doctoral programs. Ecosystems 2:281-285. http://dx.doi.org/10.1007/s $\underline{100219900076}$

Haapasaari P. 2008. Tieteiden välisen tutkimuksen mahdollisuudet ja haasteet kalavarojen hallinnassa (Potential and challenges of interdisciplinary cooperation for fisheries management). Pages 97-114 in T. P. Karjalainen, P. Luoma, and K. Reinikainen, editors. Ympäristösosiologian virrat ja verkostot (Flows and networks of environmental sociology). Oulun yliopisto, Thule-instituutti, Yliopistopaino, Oulu, Finland. In Finnish (English abstract).

Haapasaari, P., and T. P. Karjalainen 2010. Formalizing expert knowledge to compare alternative management plans: sociological perspective to the future management of Baltic salmon stocks. Marine Policy 34:477-486. http://dx.doi.org/1 0.1016/j.marpol.2009.10.002

Haapasaari, P., T. P. Karjalainen, K. Reinikainen, and C. Michielsens. 2005. Commitment to salmon: using Bayesian modeling to create a sustainable fisheries management tool based on commitment of fishermen. Paper number ICES CM 2005/V:07 in Proceedings of ICES Annual Science Conference, 20-24 September 2005, Aberdeen, Scotland. International Council for Exploration of the Sea, Copenhagen, Denmark.

Haapasaari, P., C. G. J. Michielsens, T. P. Karjalainen, K. Reinikainen, and S. Kuikka. 2007. Management measures and fishers' commitment to sustainable exploitation: a case study of Atlantic salmon fisheries in the Baltic Sea. ICES Journal of Marine Science 64:825-833. http://dx.doi.org/10.1093/ices $\mathrm{jms} / \mathrm{fsm} 002$

Heemskerk, M., K. Wilson, and M. Pavao-Zuckerman. 2003. Conceptual models as tools for communication across disciplines. Conservation Ecology 7(3):8.

Huutoniemi, K., J. T. Klein, H. Bruun, and J. Hukkinen. 2010. Analyzing interdisciplinarity: typology and indicators. Research Policy 39:79-88. http://dx.doi.org/10.1016/j.respol. $\underline{2009.09 .011}$

International Council for the Exploration of the Sea (ICES). 2002. Report of the Baltic Salmon and Trout Assessment Working Group, 3-12 April 2002. Riga, Latvia. ICES CM 2002/ACFM:13. Advisory Committee on Fishery Management, Copenhagen, Denmark.

International Council for the Exploration of the Sea (ICES). 2010. Report of the Working Group on Baltic Salmon and Trout (WGBAST), 24-31 March 2010, St. Petersburg, Russia. ICES Advisory Report 2010, ICES CM 2010/ACOM:08. ICES Advisory Committee, Copenhagen, Denmark. [online] URL: http://www.ices.dk/reports/ACOM/2010/WGBAST/wgbast 2010. pdf. 
Jensen, F. V. 2001. Bayesian Networks and Decision Graphs. Springer, New York, USA. http://dx.doi.org/10.1007/978-0-3 87-68282-2

Klein, J. T. 1990. Interdisciplinarity. History, Theory, and Practice. Wayne State University Press, Detroit, Michigan, USA. http://dx.doi.org/10.4135/9781848607958.n2

Klein, J. T., W. Grossenbacher-Mansuy, R. Häberli, A. Bill, R. W. Scholz, and M. Welti. 2001. Transdisciplinarity: Joint problem-solving among Science, Technology, and Society. Birkhauser Verlag, Basel, Switzerland. http://dx.doi.org/10.1 $\underline{\text { 007/978-3-0348-8419-8 }}$

Kuikka, S., A. Delaney, R. Curtis, and A. Charles (conveners). 2009. Theme session $O$, experiences in including economic and social information in fisheries analysis and advice: why, how and by whom? Presented at the ICES Annual Science Conference 2009, Berlin, Germany. [online] URL: http://ww w.ices.dk/iceswork/asc/2009/Theme\%20sessions/TS-O-report. pdf.

Kulmala, S., M. Laukkanen, and C. Michielsens. 2005. A bioeconomic analysis of the Northern Baltic salmon fishery: management of competing sequential fisheries. Conference proceedings of $6^{\text {th }}$ International conference of the European Society for Ecological Economics, 14-17 June 2005, Lisbon, Portugal.

Kulmala, S., M. Laukkanen, and C. Michielsens. 2006. Reconciling economic and biological modelling of migratory fish stocks: optimal management of the northern Baltic salmon fishery. MTT Discussion Papers 1-2006. MTT Agrifood Research Finland, Jokioinen, Finland. [online] URL: http://w ww.mtt.fi/english/publications/dp/2006/DP2006 1.pdf.

Kulmala, S., M. Laukkanen, and C. G. J. Michielsens. 2008. Reconciling economic and biological modeling of migratory fish stocks: optimal management of the Atlantic salmon fishery in the Baltic Sea. Ecological Economics 64:716-728. http://dx.doi.org/10.1016/j.ecolecon.2007.08.002

Lattuca, L. R. 2002. Learning interdisciplinarity: sociocultural perspectives on academic work. The Journal of Higher Education 73(6):711-739. http://dx.doi.org/10.1353/jhe.2002.0054

Levontin, P., S. Kulmala, P. Haapasaari, and K. Parkkila. 2009. Synthesising biological, economic and sociological knowledge using Bayesian Belief Networks to support broadly based fisheries policy: the case of devising a new Baltic salmon management plan. CM 2009/O:14. Proceedings of ICES Annual Science Conference, 21-25 September 2009, Berlin, Germany. International Council for Exploration of the Sea, Copenhagen, Denmark.

Levontin, P., S. Kulmala, P. Haapasaari, and S. Kuikka. 2011. Integration of biological, economic and sociological knowledge by Bayesian belief networks: the interdisciplinary evaluation of potential Baltic salmon management plan. ICES Journal of Marine Science 68:632-638. http://dx.doi.org/10.1 093/icesjms/fsr004

Ludwig, D. 2001. The era of management is over. Ecosystems 4:758-764. http://dx.doi.org/10.1007/s10021-001-0044-x

MacMynowski, D. P. 2007. Pausing at the brink of interdisciplinarity: power and knowledge at the meeting of social and biophysical science. Ecology and Society 12(1):20. [online] URL: http://www.ecologyandsociety.org/vol12/iss1/ $\underline{\operatorname{art} 20 / .}$

Malakoff, D. 1999. Bayes offers a 'new' way to make sense of numbers. Science 19(286):1460-1464. http://dx.doi.org/10 $.1126 /$ science. 286.5444 .1460

Mäntyniemi, S., and A. Romakkaniemi. 2002. Bayesian markrecapture estimation with an application to a salmonid smolt population. Canadian Journal of Fisheries and Aquatic Sciences 59:1748-1758. http://dx.doi.org/10.1139/f02-146

Mäntyniemi, S., A. Romakkaniemi, and E. Arjas. 2005. Bayesian removal estimation of a population size under unequal catchability. Canadian Journal of Fisheries and Aquatic Sciences 62:291-300. http://dx.doi.org/10.1139/f04-195

Michielsens, C. G. J., S. Kuikka, P. Haapasaari, S. Kulmala, A. Romakkaniemi, and J. Erkinaro. 2005a. Interdisciplinary modelling through probabilistic networks: impact of fishermen's commitment on the management of wild Baltic salmon stocks. ICES CM 2005 / V:27. Proceedings of ICES Annual Science Conference, 20-24 September 2005, Aberdeen, Scotland. International Council for Exploration of the Sea, Copenhagen, Denmark.

Michielsens, C. G. J., S. Kuikka, P. Haapasaari, S. Kulmala, A. Romakkaniemi, and J. Erkinaro. 2005b. Interdisciplinary probabilistic network to examine the possibility to restore potential Baltic salmon rivers. ICES CM 2005 / W:05. Proceedings of ICES Annual Science Conference, 20-24 September 2005, Aberdeen, Scotland. International Council for Exploration of the Sea, Copenhagen, Denmark.

Michielsens, C. G. J., S. Mäntyniemi, and P. J. Vuorinen. 2006a. Estimation of annual mortality rates caused by Early Mortality Syndromes (EMS) and their impact on salmonid stock-recruit relationships. Canadian Journal of Fisheries and Aquatic Sciences 63:1968-1981.

Michielsens, C. G. J., and M. K. McAllister. 2004. A Bayesian hierarchical analysis of stock-recruit data: quantifying structural and parameter uncertainties. Canadian Journal of Fisheries and Aquatic Sciences 61:1032-1047. http://dx.doi.o rg/10.1139/f04-048

Michielsens, C. G. J., M. K. McAllister, S. Kuikka, S. Mäntyniemi, A. Romakkaniemi, T. Pakarinen, L. Karlsson, 
and L. Uusitalo. 2008. Combining multiple Bayesian data analyses in a sequential Bayesian framework for quantitative fisheries stock assessment. Canadian Journal of Fisheries and Aquatic Sciences 65:962-974. http://dx.doi.org/10.1139/f08-015

Michielsens, C. G. J., M. K. McAllister, S. Kuikka., T. Pakarinen, L. Karlsson, A. Romakkaniemi, I. Perä, and S. Mäntyniemi. 2006b. A Bayesian state-space mark-recapture model to estimate exploitation rates in mixed-stock fisheries. Canadian Journal of Fisheries and Aquatic Sciences 63:321-334.

Miller, R. C. 1982. Varieties of interdisciplinary approaches in the social sciences: a 1981 overview. Issues in Integrative Studies 1982(1): 1-37. [online] URL: http://www.units.muohio. edu/aisorg/pubs/issues/toc_vol1.shtml.

Naiman, R. 1999. A perspective on Interdisciplinary Science. Ecosystems 2:292-293. http://dx.doi.org/10.1007/s100219900078

Nuijten, E. 2011. Combining research styles of the natural and social sciences in agricultural research. NJAS-Wageningen Journal of Life Sciences 57:197-205. http://dx.doi.org/10.1016/ j.njas.2010.10.003

Pavao-Zuckerman, M. A. 2000. The conceptual utility of models in human ecology. Journal of ecological Anthropology 4:31-56.

Pickett, S. T. A., W. R. Burch Jr., and J. M. Grove. 1999. Interdisciplinary research: maintaining the constructive impulse in a culture of criticism. Ecosystems 2(4):302-307. http://dx.doi.org/10.1007/s100219900081

Ranke, W., C. Rappe, T. Soler, P. Funegaard, L. Karlsson, and L. Thorell (editors). 1999. Baltic salmon rivers: status in the late 1990s as reported by the countries in the Baltic region. International Baltic Sea Fishery Commission (IBSFC), Warsaw, Poland; Baltic Marine Environment Commission Helsinki Commission (HELCOM); The Swedish Environmental Protection Agency, Solna, Sweden; and The Swedish National Board of Fisheries, Göteborg, Sweden.

Redman, C. 1999. Human dimensions of ecosystem studies. Ecosystems 2:296-298. http://dx.doi.org/10.1007/s100219900079

Rogoff, B. 1995. Observing sociocultural activity on three planes: participatory appropriation, guided participation, and apprenticeship. Pages 139-164 in J. V. Wertsch, P. del Rio, and A. Alvarez, editors. Sociocultural studies of mind. Cambridge University Press, USA.

Rose, R. 1976. Disciplined research and undisciplined problems. International Social Science Journal XXVIII (1):99-121.
Salmi, J., and P. Salmi. 2010. Fishing tourism, biodiversity protection and regional politics in the River Tornionjoki, Finland. Fisheries Management and Ecology 17:192-198. http://dx.doi.org/10.1111/j.1365-2400.2010.00736.x

Schwartz-Shea, P. 2006. Judging quality. Evaluative criteria and epistemic communities. Pages 89-113 in D. Yanov and P. Schwartz-Shea, editors. Interpretation and Method. Empirical research methods and the interpretive turn. M.E. Sharpe, Inc., New York, USA.

Sillitoe, P. 2004. Interdisciplinary experiences: working with indigenous knowledge in development. Interdisciplinary Science Reviews 29(1):6-23. http://dx.doi.org/10.1179/03080 $\underline{1804225012428}$

Sissenwine, M., and D. Symes. 2007. Reflections on the Common Fisheries Policy, report to the General Directorate for Fisheries and Maritime Affairs of the European Commission. Greenpeace European Unit, Brussels, Belgium. [online] URL: http://www.seas-at-risk.org/1mages/Midterm\% 20review\%20Sissenwine\%20and\%20Symes\%202007.pdf.

Strang, V. 2009. Integrating the social and natural sciences in environmental research: a discussion paper. Environment, Development and Sustainability 11:1-18. http://dx.doi.org/10 .1007/s10668-007-9095-2

Turner, M. G., and S. R. Carpenter. 1999. Tips and traps in interdisciplinary research. Ecosystems 2:275-276. http://dx.do i.org/10.1007/PL00010895

Upshur, R. E. G. 1999. Priors and prejudice. Theoretical medicine and bioethics 20:319-327. http://dx.doi.org/10.1023/ A:1009905701990

Uusitalo, L., S. Kuikka, and A. Romakkaniemi. 2005. Estimation of Atlantic salmon smolt carrying capacity of rivers using expert knowledge. ICES Journal of Marine Science 62 (4):708-722. http://dx.doi.org/10.1016/j.icesjms.2005.02.005

Varis, O., and S. Kuikka. 1997. Joint use of multiple environmental assessment models by a Bayesian meta-model: the Baltic salmon case. Ecological Modelling 102:341-351. http://dx.doi.org/10.1016/S0304-3800(97)00068-9

Wertsch, J. V., P. del Rio, and A. Alvarez. 1995. Sociocultural studies: history, action, and mediation. Pages 1-34 in J.V. Wertsch, P. del Rio, and A. Alvarez, editors. Sociocultural studies of mind. Cambridge University Press, Cambridge, England.

Erratum: The word "epoch" was used in the original published version of this paper. It has been changed to "epochè" following DeWachter (1982). The change was made 26 March 2012. 